Provided by the author(s) and NUI Galway in accordance with publisher policies. Please cite the published version when available.

\begin{tabular}{|c|c|}
\hline Title & $\begin{array}{l}\text { Education in precarious times: a comparative study across six } \\
\text { countries to identify design priorities for mobile learning in a } \\
\text { pandemic }\end{array}$ \\
\hline Author(s) & $\begin{array}{l}\text { Hall, Tony; Connolly, Cornelia; Ó Grádaigh, Seán; Burden, } \\
\text { Kevin; Kearney, Matthew; Schuck, Sandy; Bottema, Jeroen; } \\
\text { Hustinx, Wouter; Evens, Marie; Koenraad, Ton; Makridou, } \\
\text { Eria; Cazemier, Gerton; Kosmas, Panagiotis }\end{array}$ \\
\hline $\begin{array}{l}\text { Publication } \\
\text { Date }\end{array}$ & 2020-06-25 \\
\hline $\begin{array}{l}\text { Publication } \\
\text { Information }\end{array}$ & $\begin{array}{l}\text { Hall, Tony, Connolly, Cornelia, Ó Grádaigh, Seán, Burden, } \\
\text { Kevin, Kearney, Matthew, Schuck, Sandy, Bottema, Jeroen, } \\
\text { Cazemier, Gerton, Hustinx, Wouter, Evens, Marie, Koenraad, } \\
\text { Ton, Makridou, Eria, Kosmas, Panagiotis. (2020). Education in } \\
\text { precarious times: a comparative study across six countries to } \\
\text { identify design priorities for mobile learning in a pandemic. } \\
\text { Information and Learning Science. doi:10.1108/ILS-04-2020- } \\
0089\end{array}$ \\
\hline Publisher & Emerald \\
\hline $\begin{array}{l}\text { Link to } \\
\text { publisher's } \\
\text { version }\end{array}$ & https://dx.doi.org/10.1108/ILS-04-2020-0089 \\
\hline Item record & http://hdl.handle.net/10379/16051 \\
\hline DOI & http://dx.doi.org/10.1108/ILS-04-2020-0089 \\
\hline
\end{tabular}

Some rights reserved. For more information, please see the item record link above. 


\title{
Education in Precarious Times: A Comparative Study Across 6 Countries to Identify Design Priorities for Mobile Learning in a Pandemic
}

Tony Hall ${ }^{1}$; Cornelia Connolly ${ }^{1}$; Seán Ó Grádaigh ${ }^{1}$; Kevin Burden ${ }^{2}$; Matthew Kearney $^{3}$; Sandy Schuck ${ }^{3}$; Jeroen Bottema ${ }^{4}$; Wouter Hustinx ${ }^{5}$; Marie Evens ${ }^{5}$; Ton Koenraad $^{6}$; Eria Makridou ${ }^{7}$; Gerton Cazemier ${ }^{4}$; Panagiotis Kosmas ${ }^{7}$

${ }^{1}$ School of Education, National University of Ireland, Galway

${ }^{2}$ Faculty of Arts, Cultures and Education, University of Hull, UK

${ }^{3}$ STEM Education Futures, University of Technology, Sydney, Australia

${ }^{4}$ Teaching, Learning \& Technology, Hogeschool Inholland, The Netherlands

${ }^{5}$ Hogeschool PXL, Hasselt, Belgium

${ }^{6}$ TELLConsult, The Netherlands

${ }^{7}$ CARDET (Center for the Advancement of Research \& Development in Educational Technology), Cyprus

\begin{abstract}
Similar to the current global Coronavirus crisis, the flu pandemic of 1918 forced the closure internationally of schools, and in general brought a halt to formal education. A major difference between then and now is that there was no possibility at that time to move education online; and furthermore, even in the current era, mobile learning has really only become generally usable and ubiquitous in the last twenty years, through the increased connectivity, functionality and portability of mobile devices. This paper is based on the emergency changes we have had to make in the European DEIMP Project (2017-2020), 'Designing and Evaluating Innovative Mobile Pedagogies'. DEIMP is undertaken by a transnational consortium comprising partner institutions and schools from six countries: the UK (coordinating), Australia, Belgium, Cyprus, Ireland, and the Netherlands. Based on its work developing educational technology with and for schools, DEIMP has produced twenty-one principles underpinning innovative mobile pedagogies, clustered in five themes: adaptive, authentic, collaboration, mobility, and student choice. It is possible to see evidence of the principles in the mobile learning responses in different countries, as a consequence of the current, COVID-19 Pandemic. However, for effective coordination to happen across the twenty-one principles, this study highlights how both the digital divide and digital use divide need to be uniformly tackled and addressed. Solving these two priority challenges as well as implementing the twentyone principles will, we hope, help us respond effectively in the uncertain present, and plan systematically for an unpredictable, post-pandemic future.
\end{abstract}

\section{Introduction - An Unprecedented Pandemic}

The current pandemic caused by the worldwide spread of COVID-19 is being described as a global crisis without precedent. The imperative for education to respond to the "warnings of impending pandemics" had been noted - though only in one study we are aware of (Parker White et al, 2010, p 34) following the SARS outbreak in 2002-2003 and H1N1 influenza pandemic of 2009.

In the discourse on educational technology, information and learning sciences, it is hard to find references to pandemics and thus potential implications for education. Indeed, historical references to educational disruption owing to the pandemic of 19181919 are more likely to be found in epidemiological and health policy journals (e.g., 
Stern et al., 2009). The current crisis seems in general to have been completely unanticipated in educational research.

This paper has emerged in the context of our work within the European DEIMP Project (2017-2020), 'Designing and Evaluating Innovative Mobile Pedagogies'. As well as the enforced changes to the project, there have been major adjustments in how education is being provided in each of our countries, across all sectors: early years, primary, secondary and tertiary.

As there is the likelihood - probably high - that this pandemic may become endemic (annual/recurring), it underscores the need for us to learn from the present crisis. In this paper, we illustrate how six different countries have responded to emergency transitions to remote online education. Within the constraints of a short paper, it is not possible to explore all the variables of the complex and challenging context that currently prevails in education and society. Rather, what we have tried to do is highlight salient issues and developments, and consequently what we might be able to learn through comparison of key aspects of the emergency responses across the multiple jurisdictions. In alphabetical order, the article exemplifies important aspects of how each have responded.

Reflecting the emergency responses in our different jurisdictions, we identify common trends, themes and technologies. In conclusion, we offer early but important insights for educational design going forward, particularly in respect of twenty-one principles for innovative mobile learning; and highlight the importance of addressing the digital divide, and related digital use divide.

\section{Australia}

Access to the Internet and technology is generally high in Australia. In a recent national census, data showed that 97 percent of households with children under the age of 15 had Internet access at home, and the mean number of devices used in these homes was 7.8 (Australian Bureau of Statistics, 2018).

At the time of writing, Australian school students have been learning remotely at home for about six weeks. Australian State government websites have developed resources and advice in support of the current remote learning context. For example, the New South Wales (NSW) State Government has developed a 'Learning from Home' section to support students, teachers and parents with online teaching and learning (see https://education.nsw.gov.au/teaching-and-learning/learning-fromhome). Video-conferencing facilities such as Zoom are popular, as are collaborative cloud-based documents such as Google Documents (see https://app.education.nsw.gov.au/digital-learning-selector/).

Preliminary findings from a recent survey indicate that although teachers have reported an increase in their digital skill levels, they are anxious and under-prepared. Also, parents are struggling to combine their own work with their new roles of facilitating schooling at home, and there are serious equity concerns for students with limited access to technology and for students learning at home without parental assistance (Duffy \& Kent, 2020).

Early reports seem to indicate a dominant presentational or 'information delivery' approach to online teaching (e.g., Karp \& McGowan, 2020). This default 'chalk and talk' approach is totally understandable given the minimal preparation Australian teachers were given before moving to a remote teaching and learning situation. 


\section{Belgium}

Since March 16 universities and K-12 schools in Flanders have been closed. In higher education, all classroom-based learning activities have been suspended and replaced with distance education. It is expected that universities in Flanders will keep using distance education until the end of the academic year.

In the first weeks, remote education in K-12 schools only focused on repetition of previously taught learning content. No new learning content could be introduced. Policy changed in April 2020 when 'pre-teaching' was introduced. K-12 schools are expected to teach small packages of new information to students that will later be elaborated on in the classroom, probably from May 15 (Onderwijs Vlaanderen, 2020).

Infrastructure for distance education is rather advanced in Flanders. Most families have mobile devices and access to the Internet. The government is also collecting laptops to provide them to students who do not have one at home (DigitalForYouth, 2020). Several telecom providers are temporarily offering free Internet connectivity and a number online platforms are being used in both higher and K-12 education, including Google Hangouts, Smartschool, Microsoft Teams, and Blackboard. At all educational levels, educators teach both synchronously (live courses) and asynchronously (assignments, instructional videos, feedback). Asynchronous teaching seems to be the dominant model, compared to the synchronous modality.

In higher education, the difference between education before and during the pandemic is much smaller than in K-12 education. Blended learning was already very common in Flemish higher education. Hence, the switch to exclusively remote education was feasible for most universities. Most students have their own laptop as well. In K-12 education, the concept of pre-teaching is now trending. Most teachers organise this pre-teaching by developing instructional videos, containing explanations, a worked example and an oral instruction. Teachers share videos and related worksheets with their students on a daily basis. Students are expected to correct themselves afterwards. This approach might be beneficial for the development of autonomous learning and therewith students' self-regulatory skills.

Concerning evaluation and assessment, the situation in Flanders differs from other countries, as in Flanders there are no centralized examinations. K-12 schools have pedagogical freedom, which means that they decide autonomously whether or not exams are necessary at the end of the school year, and how these exams are designed and organized. In higher education, most exams will take place online, with fraud prevention software (Respondus, Proctorio) and plagiarism checks on assignments (TurnItIn, SafeAssign) used to ensure academic integrity.

\section{Cyprus}

Before the pandemic, the education system in Cyprus was almost entirely based on synchronous learning activities. The substantial integration of technology, especially in public education, was absent. There was no concrete framework for distance education, and only some higher education institutions had policies and schedules for online learning. The educational system of Cyprus was not ready to deploy a $100 \%$ distance education plan, specifically in K-12 and secondary schools. As announced by the Ministry of Education, Culture, Sports and Youth, schools and universities across Cyprus had to close as a precautionary measure to contain the spread of COVID-19, and during these times of school closure more than 110,000 teachers and students joined and had access to the Distance Education System 
developed by the Ministry. To facilitate this transition to online learning, some of the key actions that the Ministry has implemented, include (MOEC, 2020):

- Connection to the Internet of all households for all children to participate in distance education and avail of the necessary pedagogical support;

- 2,000 tablet computers have been provided to schools for use in the distance learning program so that all children can access its educational supports remotely educational;

- A new website of the Ministry of Education has been launched (http://elearning.schools.ac.cy/), as one useful guide for distance learning;

- Free use of MS TEAMS (Office365) for all schools;

- Asynchronous training for all teachers on how to use the virtual classrooms, based on the Microsoft Teams platform.

\section{Ireland}

Irish schools and universities closed on March 12, in order to mitigate community transmission of the disease. The response of schools and teachers to this crisis has been characterised by very diverse reactions, exacerbated by the fact that technology provision in schools is very mixed. Some have extensive technology infrastructure whereas others are not as well equipped. $63 \%$ of respondents to a school survey one week into lockdown (Burke \& Dempsey, 2020) believed school closures would have a negative effect, with detrimental impact on academic progress being a concern (but not the priority). There was more of a focus by respondents on the formative, socialisation aspects of schooling, and particular concern was expressed for students with special educational needs and those from socioeconomically disadvantaged backgrounds. $58 \%$ of schools considered broadband connectivity a priority when making strategic decisions for the closure period, with concerns raised about disparities in access and the 'digital divide'. $43 \%$ of teachers are in contact with students once a week, and $29 \%$ on a daily basis. In regard to the effects of school closure on staff, increased stress was highlighted, particularly lack of training; concern for students and their general wellbeing; complexity of competing demands at home; and perception of unrealistic expectations from parents/media. Teachers' learning new skills has been seen as a positive outcome, as well as the necessity for increased collegiality and teamwork.

Large-scale schooling at home data (1200 respondents, 459 parents) were also collected in Ireland in early April 2020 (Doyle, 2020), which indicated that parents are typically spending 1-2 hours on their children's formal learning. However, parents with lower educational attainment are less likely to use resources from teachers, educational apps, or the HomeSchool Hub (a COVID19 response, educational television programme provided by the national broadcaster, RTÉ). The same report indicated $25 \%$ of children accessed virtual classes, $80 \%$ received texts/emails from schools with the majority of resources sent by schools (90\%) described as homework. Guidance was issued to all schools by the Department of Education and Skills on continuity of schooling to support learners with special educational needs and learners from disadvantaged backgrounds. The Government also announced ICT funding ( $€ 10$ million) for schools in relation to the provision of laptop devices to final year examination students. This funding was part of the broader suite of measures to support all students, and particularly those most at risk due to COVID-19 enforced school closures. 


\section{The Netherlands}

Schools in primary, secondary, vocational and higher education have been closed since March 16 with the exception of children of parents with 'essential jobs' (e.g. healthcare, education, public transport) (Rijksoverheid, 2020). It is anticipated that K-12 schools will have resumed organizing activities in schools before the start of the summer holidays, albeit in a customized manner in keeping with regulations issued by the National Institute for Public Health and the Environment (Algemene Vereniging Schoolleiders, 2020). It is expected that universities will organize distance and online education until the end of the academic year, although some facilities \& buildings (library, research labs) are still accessible.

As a result of the measures schools and universities faced decisions about how to continue teaching and learning and mandated that teachers and faculty move education online within a matter of days, requiring not only an enormous effort and flexibility from teachers and educational support staff, but also from students and their respective home-situation.

The Netherlands has an advanced digital economy and the extent to which the Internet is available to everyone is high (de Heij, 2019). The use of technology for teaching and learning is widely adopted in Dutch education (ten Brummelhuis \& Binda, 2017; Bijleveld \& Heuzels, 2020; SURF, Vereniging van Universiteiten \& Vereniging van Hogescholen, 2018) with access to computer labs, tablets, interactive whiteboards, and fast Internet at almost all school locations with a growing interest in the implementation of mobile technology (Bottema, 2016).

Although the infrastructure for online and distance education in the Netherlands is quite advanced, access to equitable education was not self-evident, induced by the scramble to move education online (Maas, 2020; Florissen, 2020). Teachers worry about students with difficult home-situations and learners with special educational needs. A number of measures were issued by the government, addressing the support of children, living in vulnerable environments, in primary and secondary education and providing them with laptops (Maas, 2020). Initial findings of research into school shut down in the Netherlands provide clear indications that it is likely to have strong effects on the inequality in educational opportunities related both to differences in online input and support for schooling at home (Bol, 2020).

Teachers express the need for support in designing and delivering effective online education. At all levels in education, through formal and informal (social media) channels, teacher (and parent) support for designing and delivering online education was organized, e.g. Lesopafstand.nl, a collaborative effort of multiple national education agencies (Kennisnet, 2020). WikiWijs, a national exchange platform for educational materials, reported an increase of $41.55 \%$ of its registered membership after the widespread closure of schools (Wikiwijs.nl, 2020). In the research of Meulendijks \& Pavias (2020) teachers in higher education institutes expressed the need for examples and ideas for designing and delivering effective online education, and also mentioned experiencing information overload and problems distinguishing between different sources of information.

\section{$\boldsymbol{U K}$}

Following a near universal pattern, England, Wales and Scotland announced the closure of schools towards the end of March 2020 with the exception of the children of essential workers such as health care operatives and supermarket staff. It was anticipated this would amount to approximately $10 \%$ of the normal school population and schools initially organised staffing cover accordingly. In practice less 
than $2 \%$ of school aged students are reported to be attending formal schooling over the resulting period leaving a huge volume of learners who most schools are illequipped or prepared to cater for remotely. Most of this $2 \%$ appear to be primary schools (K1-6) with a lesser number in secondary schools and sixth form colleges (K7-13).

Although most schools across the UK have broadband access to the Internet this is not true for many households and connectivity still varies considerably especially in rural and remote areas where broadband is far less common than in large urban centres. Even among schools with robust and pervasive Internet connectivity, relatively few have invested in the resources, training and liaison with parents to support home-school learning that is comparable to the experience of direct schooling itself. The response of schools and teachers to this crisis across all three nations has been characterised by the extent of its variation, ranging from full-scale online distance learning with full conferencing facilities at one end of the spectrum, through to traditional, paper based worksheet activities that students are expected to complete individually, with little of no support and supervision at the other end. The COVID-19 crisis has highlighted the value and potential of digital tools such as personal mobile phones, that were often banned or at best marginalised as learning technologies less than two months ago. However, it has also thrown into sharp relief the extent to which many institutions are still designed and organized around traditional patterns of face to face teaching, fixed times and monolithic patterns of thinking that have not evolved to grasp the more nuanced and differentiated opportunities for learning that digital technologies offer when they are implemented thoughtfully and in a principled manner. It is not necessarily a lack of technology or imagination from teachers that has created this situation and a small number of lighthouse schools such as de Ferrers Academy in Burton-upon-Trent have demonstrated how a carefully designed approach to using digital technologies to overcome many of the traditional barriers of space and time can be highly effective and can actually address many of the equity issues that have raised concern about households that do not have the means available to provide laptops or high speed connectivity that many forms of online learning require.

\section{Discussion - Principles for Innovative Mobile Learning}

Although systematic research on a national scale is lacking at this moment, in general the trend is that teachers are adapting 'traditional' classroom pedagogies, developing instructional videos, organizing webinars, and sharing learning materials and assignments online. What was previously done face-to-face is now being done online. More student-centred online activities, such as applying knowledge in practice tasks, organizing peer review or using collaborative learning, seem to be less used by teachers. Developing these activities require from teachers specific pedagogical-, content- and technological knowledge and skills. Research into the experiences with developing online education of teachers from a large higher education institute in the Randstad (Meulendijks \& Pavias, 2020), but also communication via social media outlets such as Twitter and LinkedIn and more traditional news channels (e.g. Hermans, 2020) seems to confirm this trend.

A small group of universities such as Edinburgh and Leeds have developed the infrastructure and resources to provide at least a comparable learning experience for students based on many years of investment and staff development. However, for the majority of university providers, e.g. across the UK, they have neither the resources nor the inclination to support online and distance learning at this quality and 
scale and most seem to have implored their staff to convert their existing face to face provision into distance learning within a few weeks, with little or no formal training and support (Guardian, 2020).

These snapshots of how different sectors and phases of education are responding to the current crisis suggest the initial stages of a revolution that will fundamentally redesign the educational landscape we are familiar with, and in ways that have not even been imagined yet. Although we could not have anticipated or imagined the scale of the changes that the current crisis has brought about when we initiated the DEIMP project in 2017, it was in hindsight somewhat prescient since it was predicated on the belief that existing approaches and uses to digital technologies had not altered the face of teaching and learning to any significant extent. The premise behind the project was to explore how digital technologies like the mobile phone that were increasingly pervasive and ubiquitous in many societies, could be harnessed to be more innovative in ways that would challenge and even disrupt traditional patterns of education. Based on an extensive systematic literature review of existing mobile learning research, the DEIMP team identified twenty one mobile learning principles for designing innovative mobile pedagogies that challenge existing thinking and practices around digital education. These collectively provide a framework for design as we move forward in new landscape for education and educational technology, highlighting key areas for development, including adaptive, authentic, collaboration, mobility, and student choice. It is important to note the interdependence of the principles: the more that are implemented in a mobile learning design, the greater the potential, transformative impact. However, they are not exhaustive, nor prescriptive; they must be made bespoke for the particular setting in which they are being applied. The twenty-one principles provide us a checklist of signature features of transformational mobile learning in context. The principles can also serve as an evaluation heuristic to gauge the extent of innovative learning in an existing educational design, and identify areas for further development.

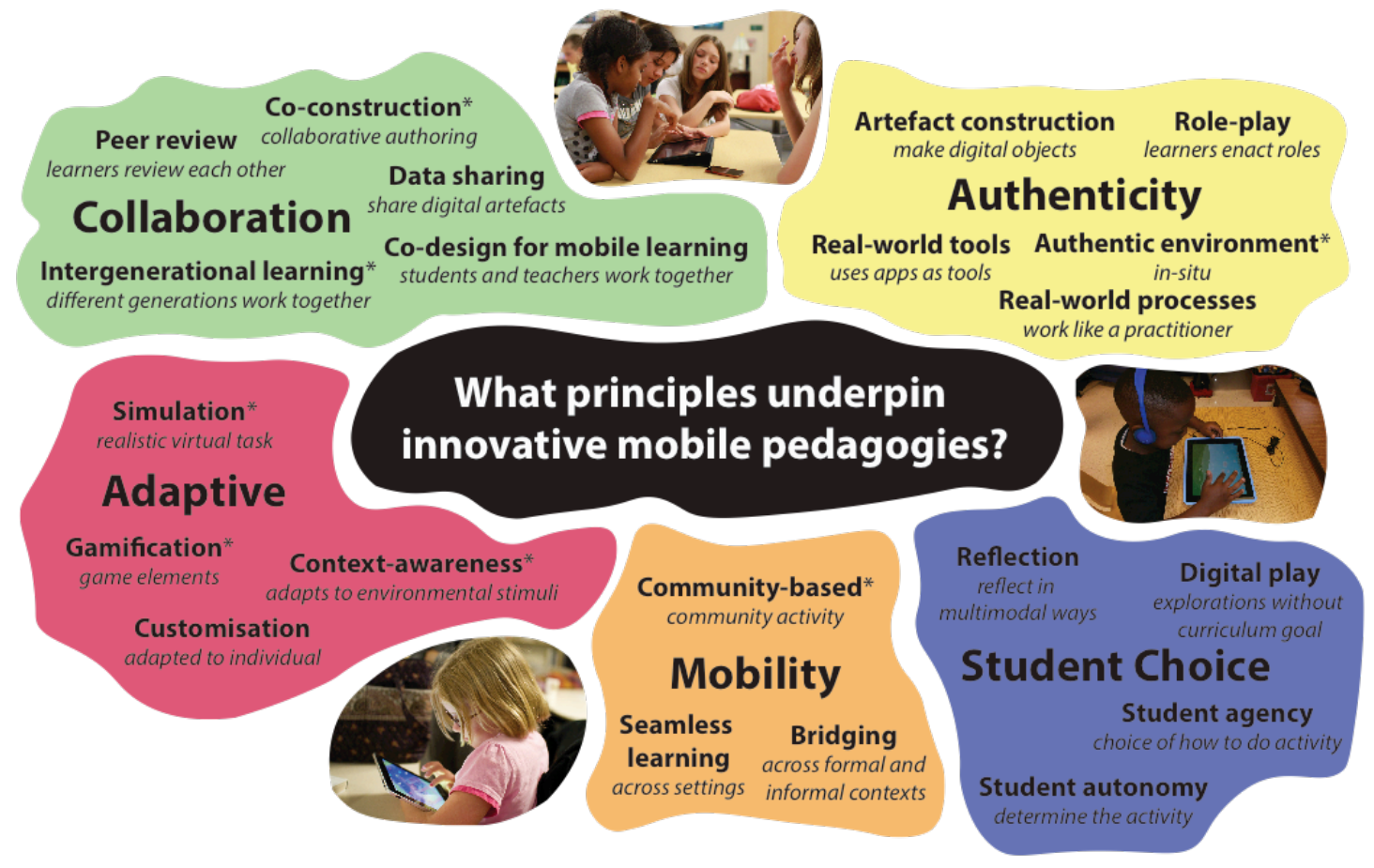

Figure 1: Principles Underpinning Innovative Mobile Pedagogies (Burden et al., 2019) 


\section{Conclusion - Educational design to tackle the digital use divide}

Looking at how the six countries have so far responded to the global pandemic, it demonstrates how well each has endeavoured to deal with what is effectively an emergency situation, unprecedented in the history of universal free public education. That the six educational systems have been able to provide some form of continuity in schooling and higher education - largely mediated by technology and the Internet - in these uniquely difficult times, reflects the professionalism and commitment of teachers, professors and educational leaders, and the care and commitment of parents, especially those engaged in enforced schooling at home. This paper has contributed some insight on the manifold demands and challenges now faced by the six educational systems. Furthermore, through comparison across the respective jurisdictions, we can note the exacerbation of the 'digital divide', the gap between the technology haves and have-nots, and the challenges faced in trying to ensure equitable access to digital education for all. Furthermore, as highlighted in the paper, a key corollary to this is the digital use divide. Previously defined by the US Department of Education (2016) the digital use divide entails the imperative to not only provide appropriate access to technology, but also effective access to expertise in how best to use technology, especially to promote interactivity in learning and teaching. Many schools have access to the Internet and devices but a lack of support/training has left teachers (and parents who are taking on the responsibility of education at home) often underprepared, and particularly in using technology beyond solely presentational modes. The efforts of teachers in the first few weeks of moving education online can aptly be described by the term emergency remote teaching (Hodges at al., 2020).

The progression to designing well-structured, evidence informed online learning experiences constitutes an important next step; not only in order to optimally engage students in remote education, but also in preparation for a more or less normalized, blended/hybrid learning situation in schools and universities. Addressing the two priority challenges of the digital divide and digital use divide, as well as implementing the twenty-one principles, can help to ensure that we achieve the original and aimed-for, transformative potential of mobile learning in the new and unanticipated normal of education systems that now rely on it.

\section{References}

Algemene Vereniging Schoolleiders. (2020) Schoolleiders al bezig met herstart, maar nog wel zorgen [online]. Available from: https://www.avs.nl/artikelen/schoolleidersal-bezig-met-herstart-maar-nog-wel-zorgen [accessed 1 May 2020].

Australian Bureau of Statistics. (2018) Household Use of Information Technology, Australia, 2016-17 [online]. Canberra, Australia: Australian Bureau of Statistics; 2018. Available from: http://www.abs.gov.au/ausstats/abs@.nsf/mf/8146.0 [accessed 1 May 2020].

Bijleveld, M., \& Heuzels, L. (2020) Ict-monitor mbo 2019. Zoetermeer: Kennisnet [online]. Available from:

https://www.kennisnet.nl/app/uploads/kennisnet/publicatie/Kennisnet-Ict-monitormbo-2019.pdf [accessed 3 May 2020]. 
Bol, T. (2020) Inequality in homeschooling during the Corona crisis in the Netherlands. First results from the LISS Panel [online]. Available from: osf.io/preprints/socarxiv/hf32q [accessed 3 May 2020].

Bottema, J. (2016) Didactische inzet van mobiele technologie in het (hoger) onderwijs. Den Haag: Lectoraat Teaching, Learning \& Technology.

Burden, K., Kearney, M., Schuck, S., \& Hall, T. (2019). Investigating the use of innovative mobile pedagogies for school-aged students: A systematic literature review. Computers \& Education, Vol. 138, pp. 83-100

Burke, J., \& Dempsey, M. (2020) Covid-19 Practice in Primary Schools in Ireland Report. [online]. Available from: https://www.into.ie/app/uploads/2020/04/Covid-19Practice-in-Primary-Schools-Report-1.pdf [accessed 6 May 2020].

de Heij, R. (2019) ICT, kennis en economie 2019. Available from: https://longreads.cbs.nl/ict-kennis-en-economie-2019/inleiding/ [accessed 1 May 2020].

DigitalForYouth. (2020) Digital for youth [online]. Available from: https://www.digitalforyouth.be/ [accessed 7 May 2020].

Doyle, O. (2020) “COVID-19: Exacerbating Educational Inequalities?” Public Policy [online]. Available from:

http://publicpolicy.ie/downloads/papers/2020/COVID_19_Exacerbating_Educational _Inequalities.pdf [accessed 3 May 2020].

Duffy, C., \& Kent, L. (2020) Parents reflect on homeschooling as teachers voice fears about schools during coronavirus pandemic [online]. Available from: https://www.abc.net.au/news/2020-04-26/coronavirus-homeschooling-remotelearning-public-private-schools/12177112 [accessed 2 May 2020].

Florissen, Y. (2020) Inclusief (online) onderwijs [online]. Available from: https://communities.surf.nl/artikel/inclusief-online-onderwijs [accessed 4 May 2020].

Guardian. (2020) Universities [online]. Available from https://www.theguardian.com/education/universities [accessed 10 May 2020].

Hodges, C., Moore, S., Lockee, B., Trust, T., \& Bond, A. (2020) "The Difference Between Emergency Remote Teaching and Online Learning". [online] Educause Review. Available from: https://er.educause.edu/articles/2020/3/the-differencebetween-emergency-remote-teaching-and-online-learning [accessed 2 May 2020].

Karp, P., \& McGowan, M. (2020) “'Clear as mud': Schools ask for online learning help as coronavirus policy confusion persists". [online] The Guardian. Available from: https://www.theguardian.com/australia-news/2020/mar/24/clear-as-mudschools-ask-for-online-learning-help-as-coronavirus-policy-confusion-persists [accessed 3 May 2020]. 
Kennisnet (2020) Lesopafstand.nl. Available from: https://www.lesopafstand.nl/ [accessed 4 May 2020].

Maas, J. (2020) Zorgen over groeiende onderwijsachterstanden door coronauitbraak. Available from: https://www.kis.nl/artikel/zorgen-over-groeiendeonderwijsachterstanden-door-corona-uitbraak [accessed 6 May 2020].

Meulendijks, G., \& Pavias, M. (2020) Verkennend onderzoek ervaringen online Onderwijs. Available from: https://presspage-productioncontent.s3 .amazonaws.com/uploads/1802/200414-overzichtsrapportage-verkennendonderzoek-onlineonderwijs-eerste-verkenning.pdf [accessed 6 May 2020].

MOEC (2020) Cyprus Ministry of Education and Culture. Available from: http://www.moec.gov.cy/en/ [accessed 4 May 2020].

Onderwijs Vlaanderen (2020) Coronavirus. Available from: https://onderwijs.vlaanderen.be/nl/nl/coronavirus [accessed 4 May 2020].

Parker White, C., Ramirez, R., Smith, J.G., Plonowski, L. (2010), “Simultaneous Delivery of a Face-to-Face Course to On-Campus and Remote Off-Campus Students", TechTrends, Vol. 54 No. 4, pp. 34-40

Rijksoverheid (2020) Poster aanvullende maatregelen voor scholen en kinderopvang. Available from: https://www.rijksoverheid.nl/documenten/publicaties/2020/03/15/poster-aanvullendemaatregelen-voor-scholen-en-kinderopvang [accessed 4 May 2020].

Stern, A.M., Cetron, M.S., \& Markel, H. (2009), "Closing The Schools: Lessons From The 1918-19 U.S. Influenza Pandemic”, Health Affairs, Vol. 28 No. 6, pp. 1066-1078

SURF, Vereniging van Universiteiten \& Vereniging van Hogescholen (2018, May) Versnellingsplan Onderwijsinnovatie met ICT. Available from: https://versnellingsplan.nl/over-versnellingsplan/ [accessed 3 May 2020].

ten Brummelhuis, A., \& Binda, A. (2017) De Vier in balans-monitor 2017. Zoetermeer: Kennisnet. Available from: https://www.kennisnet.nl/app/uploads/kennisnet/publicatie/vierinbalans/Vier-inbalans-monitor-2017-Kennisnet.pdf [accessed 5 May 2020].

US Department of Education (2016) National Education Technology Plan. Available from: http://tech.ed.gov [accessed 5 May 2020].

WikiWijs (2020) https://www.wikiwijs.nl/. Available from: https://www.wikiwijs.nl/ [accessed 4 May 2020]. 